\title{
新幹線に使われるばね \\ The Springs and the New Tokaido Line
}

新幹線に使われるばねの種類は現在線の場合同様非常 に多く多岐にわたっているが，現在線に使われていない 全く新しいばねというのは少ない。しかし，新幹線は現 在線に比べて, 列本.運行速度が大きいといら点が最大の 特徴であって, そのため起り得る各種の振動の種類, 大 きさなどの特性を想定し，これをいかに吸収するかが大 きな問題であり,ばねとしてもこの意味から調查，研究， 試作が進められ現車試験の結果を種々検討, 改良が加え られて漸く量産化が決定した。特に話題となるような 二・三のばねを取上げて紹介する。

\section{1. 架 線 関 係}

電車の集電装置として最も優秀な架空電車線方式で も，集電速度が大きくなると，パンタグラフすり板がし ばしば電車線から離机て離線という現象を起し，満足な 集電ができなくなる。すなわち集電限界速度があり，た とえば現在線のシンプルカテナリーでは $140 \mathrm{~km} / \mathrm{h}$ 程度 である。新幹線の場合には $200 \sim 250 \mathrm{~km} / \mathrm{h}$ の速度が想定 され，そのため架線構造を全く新しい様式にした。すな わち合成架線である。合成架線とは「適当なばね定数, 等価質量, 機械抵抗をもった合成架線素子を作り, これ を架線の一部に捙入し，架線の三要素を架線各点で均一 とした架線」である。合成架線素子は要するに適当な架 線の三要素をもっていればよいのであって，弾性作用と してはコイルばね，板ばねなど各種のばね，ダンパとし ては空気, 油, 固体摩擦など種々のものが利用できる。 多くの実用試験の結果, コイルばね, 空気ダンパ併用 型の合成架線線子に決定した。最終的にはコイルばねは 3.5 または $3.8 \mathrm{~mm}$ のピアノ線を用いた初張力を有する 引張コイルばねで，そのばね定数は $0.05 ， 0.10 ， 0.20$ $\mathrm{kg} / \mathrm{mm}$ であった。このばねにエポキン樹脂塗料を浸漬 焼付の上, リテーナとの接触部分には防錆グリースを塗 布して，さらに空気多ン゚゚共にステンレス鋼製の筒の 中に組み入れられている。

なおこの外に風圧などによる架線の振止め抒よび曲線

* 鉄道技術研究所

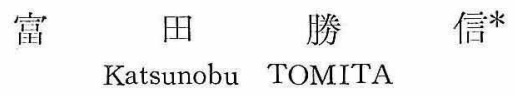

引きのための金具が使用されているが，これにはステン レス鋼線製の引張コイルばねが用いられている。

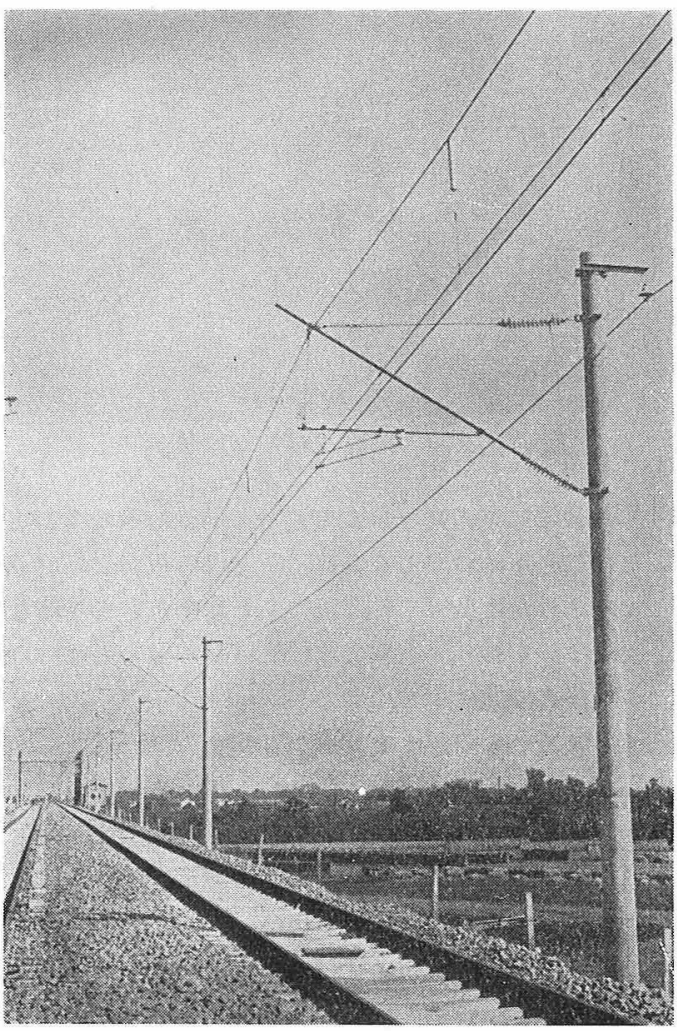

第 1 図 合成架線素子㧍よび振止め防止金具

\section{2. 莗 両関 係}

2.1 マクラばねとしては現在線に肪いて空気ばねが 相当使用されて来たが，ばねが横方向にやわらかい ので，一般にアンチローリング機構が使われている。 新幹線としては横変位に対する安定性のすぐれた特殊 なダイヤフラム形空気ばねに落着いた。なお左右動ダ ンパが併用されている。

2.2 軸ばねとしてはウイング式で直径 $30 \mathrm{~mm}$ と 20 $\mathrm{mm}$ の SUP9のミガキコイルばねが用いられて㧍り， 今までは余りつかわれていなかった軸ばねダンパが併 
用されている。

2.3 従来の台車の軸箱支持方法は大部分軸箱と台車 枠の間にすり板を使用するすり板方式であったが，す り板の摩擦と共に蛇行動に対する性能が悪化する。蛇 行動防止のために試作されたミンデン式を始めとして 各種の軸箱支持装置について諸種の試験を行い検討し た。その結果新しく考案したI S 式軸箱支持装置の採 用となった。これは軸箱の前後に撓み板を固定し，そ

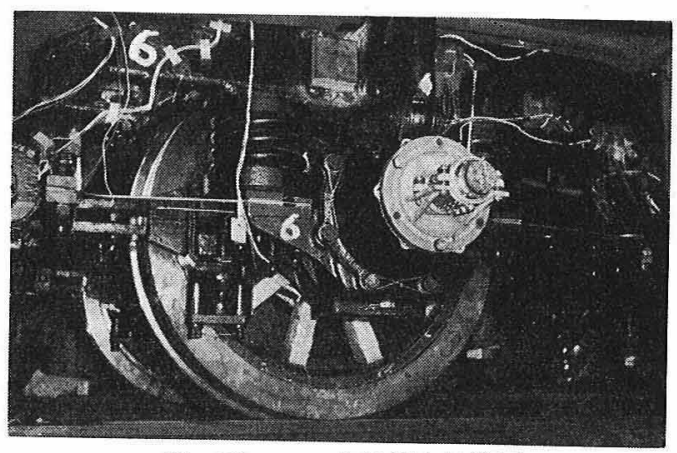

第 2 図 I S 式軸箱支持装置

の前後端にゴムブッシュを使って前後左右のばね定数 を一定範囲に拉さえている。また撓み板执よびブッシ ュのたわみによって軸ばねの上下運動をさまたげない ようにしており，摩擦もなければ摩擦部分もない。ボ ルト締めの他に一方の端の一部にセレーションを設 け, 軸箱にも同様にセレーションを設け, 互いにかみ 合せて，大きな獚圧が作用しても撓み板が廻らないよ らにしてある。撓み板の板币の中央部には巾 $30 \mathrm{~mm}$ の 瑇が軸箱寄りの長さ方向のほぼ中央まであり，撓み板 にたとえ象裂が入っても折損にいたらないように工夫 されている。

材料は $\mathrm{Cr}-\mathrm{V}$ 鋼で加工，熱処理後表面は研磨仕上を し，その上にポリウレタン樹脂系の塗料で表面を保護 している。

2.4 異常蛇行動防止のためにピン,ブッシュのない, がたのないボルスタアンカが用いられ, 前後弾性が適 当で, 上下左右, コジリ方向にはほとんど抵抗のない ものとした。心棒として中空の軸を用い，その両端に 金具をとりつけその中に半割りの球形ゴムをだいてい る。

2.5 その他パンタグラフ用として $10 \mathrm{~mm} \phi$ の主ばね と並列にオイルダンパ (下げに対して片效き) を 1 個 入れて上下動共振時の振巾の增加を防止したり, 腰掛 け背ずりにSばねを横にならべ，腰椎骨の当たる部分
にはつづみ型コイルばねを組合せて使ったり，その他 各種の機器の内部に数多くの種々のばねが使用されて いるのは勿諭である。

\section{3. 軌 道 関 係}

軌道関係では十数年前コンクリート枕木の出現にやや 後れて, 従来犬釗で止められていたレ一ルの締結にばね (スプリングクリップといっている）を用いたいわゆる 弾性締結法が採用された。その後逐次試作改良が加えら れ, 各種の弾性締結法が使用され, その有効性がたしか められていた。またその使用量も年と其に急增した。

新幹線の場合には $25 m$ レールを溶接または圧接した 長大レール $(1500 m)$ を使用することになり, さらに鉄 橋以外の大部分の枕木は PC コンクリート枕木を使用す ることになり，充分しっかりした弾性締結が必要であ る。さらに列車の運行速度が大きいため従来より大きい 横圧（レールを横方向に押す力）が発生することが想定 された。

そこで 102 型と称する特殊な締結装置が採用された。 その締結装置のばねとしては主ばね, 横押えばね, 円形 ばねの三種類が使われており, 主ばね, 円形ばねは主と して上下振動の吸収に働き, 横押えばねは常時はレール 側方にわずかに密着していて, 時に発生する大きな横圧

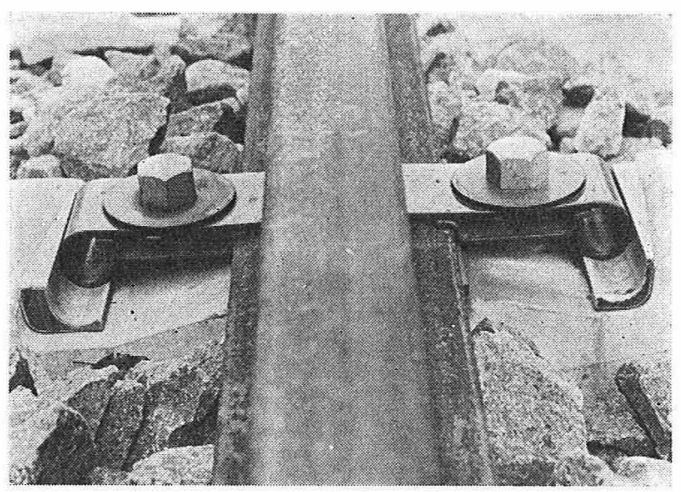

第 3 図 102型 弹性締結装置

に耐えるようにしたものである。横押えばねはは始めて の試みであり，その必要性が相当論議されたようである が，設計者の想定どおり，モデル線（綾瀬一鴊ノ宮）に おける $200 \sim 250 \mathrm{~km} / \mathrm{h}$ 運転の際の強列な横圧（特別に 条件を最悪にして行った実験の場合に発生した）の発生 に対して見事その機能を発揮した。

従来の各種のスプリングクリップは平均応力約 $60 \mathrm{~kg} /$ $\mathrm{mm}^{2}$ になるように締付け，応力振巾はわりに大きい型 
式であったが，新幹線に㧍いては，一㭙に膨大な量を必 要とし（約 600 万七ット）経済的な面加も，平均応力 約 $100 \mathrm{~kg} / \mathrm{mm}^{2}$ で忘力振巾を極力少くするように設計さ れ、ばね重量を極端にへらした。このためばね製造面で は性能保持のために各種の制約が設けられた。しかし試 験項目はできるだけ必要性を充分吟味して取捨選択が行 われた。すなわち材料としては SUP 9 または SUP 6 と し，その選択はばねメ一カの自由意志に委された（しか し実際に製造されたものは全て SUP 9 であった)。ばね 硬さはブリネル円痕径で $3.0 \sim 3.2 \mathrm{~mm}$ とし, 従来のも のの範囲で高目の方にせばめた（従来は $3.0 \sim 3.3 \mathrm{~mm}$ で あった)。また始めに弾性試験，曲げ試験などが提案さ れたが，種々の実験の結果から，これらを試験項目から 除いても他の試験に合格すれば充分満足する性能が保証 されることが判った。

従来のスプリングクリップは腐食のために折損するこ とが多かったので，すでに数年前から実施していた軌道 防食法の研究（数十種類の防食法について）の途中成果 を利用して特殊な防食法を行らこととした。すなわち， スプリングクリップはショットピーニングを行い, 直ち
にジンクリッチペイント（従来のジンクダストペイント 之異なり Zn 粉末の\%が多いもの) を塗布乾燥し，その 上にフタル酸樹脂エナメルを 2 回塗布焼付けを行うこと で電気化学的防食効果を衫らった。また海岸線から $1 \mathrm{~km}$ 以内の場所および長大ずい道内のスプリングクリップ （約 90 万七ット）はショットブラスト（酸洗いは禁止し た）した上に溶融亜鉛めつきを行った。溶融亜鉛めっき は従来から一部のスプリングクリップにはすでに実施し ていたが、ジンクリッチペイントについては，ばねに利 用されたのは始めてであろらし，またこれだけ大量に使 用されたことも始めてであろう。従ってばねメ一カは各 社共, ば敖造設備の新設, 増設はもとより塗装関係の 設備の新設を実施し，塗装技術の向上，塗料の改善に見 るべきものがあり，日本のばね界，塗料界のためにも非 常によいことであった。

なおこの外に，ずい道または高架上木ブロック直結用 タイプレート，橋上ロングレール用タイプレート，レー ル継目用タイプレートのクリップとして特殊なスプリン グクリップ，ワッシャーなどが用いられている。 